\title{
ПОЕТОАОГІЧНІ СТУАIї
}

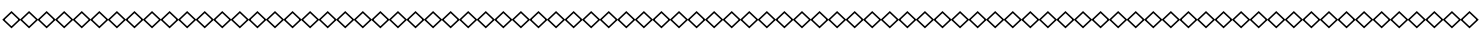

\author{
УДК 821.111.09
}

DOI https://doi.org/10.32840/1813-341X-2019-2.02

H. В. Гутарук

аспірант кафедри англійської фрілології та зарубіжної літератури Класичного приватного університету

\section{ОБРАЗНО-ДИСКУРСИВНИЙ ХАРАКТЕР РЕПРЕЗЕНТАЦІЇ ДИТИНИ У ТРАКТАТІ РОДЖЕРА ЕШЕМА «ШКІЛЬНИЙ ВЧИТЕЛЬ»}

Ренесансний гуманіст Р. Ешем (1515-1568 рр.) відомий широкому загалу завдяки двом трактатам: "Токсофріл» (був опублікований за життя автора - у 1545 р.), який артикулює авторську позицію щодо ролі фрізичного розвитку у прочесі виховання, та «Шкільний вчитель» (виданий посмертно - у 1570 р.). Для того часу публікація трактату вже після смерті автора є досить цікавим фрактом, що свідчить про те, що своєрідний механізм роздумів і реакції суспільства, який Р. Ешем запустив у 1545 р. своїм першим етико-педагогічним твором, потребував логічного продовження й розвитку. Кількість редакцій і подальших видань трактату, здійснених у період із 1570 р. по 2015 р., налічує більше ста, що свідчить про неабиякий інтерес як тогочасного суспільства, так і подальших поколінь до новаторських ідей ренесансного інтелектуала.

Завдяки другій грунтовній праці - «Шкільний вчитель» - ми отримуємо уявлення автора щодо різних типів інтелектуальної діяльності - так званих quick wit («щвидкий розум») ma hard wit («повільний розум»). Саме крізь призму такої авторської бінарної опозиції, обгрунтованої як теоретично, так і практично (з вдалим залученням реальних життєвих ситуацій), Р. Ешем розкриває велику кількість перцептивних домінант єлизаветинського суспільства, які дають змогу частково реконструювати специфіку сприйняття дитини в той час. Неодноразово англійський педагог акцентує увагу читачів на необхідності продуктивної співпраці в освітньому процесі між учителем, учнем та батьками, що є запорукою успішного навчання. Предтечею новітніх педагогічних теорій є ідея P. Ешема стосовно того, що процес навчання в різному віці має бути максимально наближеним до процесу гри або комунікації. Більше того, автор уперше озвучив ідею, що вчителю, окрім онтологічного досвіду й реальних життєвих обставин, необхідно враховувати також індивідуальні особливості кожної дитини, адже саме вони впливають на результат навчання.

Відтак статтю присвячено аналізу саме цих змістових акцентів, які вербалізують особливості ренесансного сприйняття дитини.

Ключові слова: дитина, дитинство, Відродження, етико-педагогічний трактат, християнсько-схоластичний підхід.

Постановка проблеми. Багатогранність сприйняття як сформованої людської особистості, так і процесу її формування озвучують у ході гострої полеміки такі гуманісти та митці доби Відродження, як Е. Роттердамський, Т. Еліот, Н. Мак'явелі та Р. Ешем. Їх діалоги й трактати, елементи яких присвячені педагогічній тематиці, $є$ абсолютно різними за стилем і способом представлення онтологічного дос- віду. Водночас їх спільною особливістю $€$ те, що увагу сфокусовано на вихованні осіб, які належали тільки до знатних родів. Формування підростаючого покоління, яке належало до інших соціальних прошарків населення, майже залишене поза увагою та зафіксоване лише в поемі С. Бранта «Корабель дурнів». Саме завдяки цій поемі ми маємо уявлення про тогочасний міметичний характер передачі життєвого досвіду як 
основний спосіб виховання дітей, що перебували поза категорією «знать» [3], однак мало що можемо сказати стосовно тогочасної рецепції самої дитини.

Світоглядні концепти Р. Ешема, сформульовані в трактаті «Шкільний вчитель», почали фрункціонувати в суспільній свідомості на правах аксіоми [7, с. 140], тому не дивно, що змістові й аксіологічні домінанти, уперше озвучені P. Ешемом, зустрічаються в подальшому на сторінках творів Д. Гасконя, Р. Гріна, Д. Лілі та інших письменників-елизаветинців.

Аналіз останніх досліджень та публікацій. Відголоски робіт педагогів-гуманістів доби Відродження можна спостерігати в багатьох сучасних літературних та етико-педагогічних творах, тому не дивно, що дослідники, які фокусуються на розгляді специфіки світської педагогічної теорії, найбільш часто звертаються до гуманістичних трактатів Р. Ешема «Токсофріл» і «Шкільний вчитель». Зокрема, вагомим внеском у дослідження відновлення особливостей ренесансного сприйняття дитини й дитинства $€$ наукові праці Л. Баткіна, Ж. Делюмо, І. Кона, О. Лілової, Н. Ревякіної, Н. Торкут, які акцентували увагу на рецепції дитини та тій ролі, яка відводиться їй саме в контексті загального історико-літературного процесу. Реконструкції поняття «дитина» як соціокультурної категорії присвячені роботи Ф. Арьєса, Л. Де Моза, Ж. Піаже.

Цінність авторських тверджень Р. Ешема для його сучасників підтверджують як факти його біографії, так і відлуння його інтелектуальних висновків на сторінках праць його сучасників. Зокрема, ренесансного гуманіста запросили викладати в Кембриджському університеті, призначили наставником принцеси Єлизавети, а також він був секретарем англійського посла при дворі Карла V, що є підтвердженням багатогранності особистості самого Р. Ешема та довіри суспільства до його інтелектуальних здобутків. Н. Торкут, розглядаючи жанрові особливості англійського ренесансного трактату, стверджує: «Ті або інші філософрські, етичні чи естетичні концепції, викладені й аргументовані на сторінках трактатів, перетворювалися на інтелектуально-духовні рушії суспільно-політичного та культурного розвитку» [7, с. 138]. Таким чином, вірогідно, що сучасна концепція сприйняття дитини загалом ґрунтується на тих принципах, які вперше були озвучені ще в XVI ст.

Гіпотеза розвідки полягає в тому, що, на відміну від педагогічних спекуляцій античних фрілософрів, витоки етико-педагогічних ідей яких беруть свій початок у міфології та багато в чому $€$ відірваними від реальності, ідеї Р. Ешема мають апробований, не відірваний від тогочасних реалій характер. Отже, хоча численні тези самого Р. Ешема вибудувані на основі концепцій давньогрецьких митців, проте він уже крізь призму християнських поглядів створював власний літературний твір та, посилаючись на Тіта Плавта, вважав за доцільне цитувати або представляти тільки ті уривки, що є носіями моральних уроків для читацької аудиторії [10]. Саме завдяки цим уривкам ми можемо реконструювати актуальні проблеми того часу, які турбували суспільство в контексті виховання підростаючого покоління, а отже, наблизитися до розуміння специфіки тогочасної рецепції дитини.

Мета статті. Мета публікації полягає в тому, щоб розглянути специфріку репрезентації концепту дитинства в етико-педагогічному трактаті Р. Ешема «Шкільний вчитель» та виокремити ті тематичні елементи, які $€$ характерним складником рецепції дитини й дитинства в єлизаветинський період.

06'єктом безпосереднього дослідження постає текст трактату «Шкільний вчитель», який дає змогу не тільки реконструювати об'єктно-суб'єктні особливості процесу навчання та виховання доби Відродження, а й розкрити тогочасні уявлення про сам «об'єкт» педагогічного впливу, тобто про дитину.

Виклад основного матеріалу. Загальновідоме твердження про те, що ми всі родом із дитинства, якнайкраще характеризує особливості сприйняття дитини в період доби Відродження, адже в той час дитинство вперше почало сприйматися не як віковий проміжок часу, а як культурний здобуток самого суспільства. Саме цьому періоду присвячене дослідження французького науковця Ф. Арьєса, який спробував відтворити як вікові межі дитинства, так і особливості тогочасного сприйняття дитини в суспільстві [2, с. 34].

За словами американського психоаналітика Л. Де Моза, уся історія дитинства $€$ «послідовним рядом більш тісних зближень між батьками та дітьми, причому кожне таке скорочення психологічної відстані $€$ приводом для нової тривоги; зменшення цієї тривожності дорослих (!) $€$ основним стимулом педагогічної практики кожного періоду» [5, с. 121]. Нагадаємо, що згідно із концепцією Л. Де Моза таких періодів шість, зокрема: 
1) інфантицидний стиль (від найдавніших часів до IV ст.);

2) відсторонюючий стиль (IV-XIII ст.);

3) амбівалентний стиль (XIV-XVII ст.);

4) нав'язливий стиль (XVIII ст.);

5) соціалізуючий стиль (XIX - середина $\mathrm{XX} \mathrm{ст.);}$

6) допомагаючий стиль (із середини XX ст.) [5, c. 123].

Наведена концепція $є$ досить дискусійною, проте її перевагою можна вважати констатацію зростаючого розуміння дорослими автономії та суб'єктності дитини, а також думку про те, що образ дитини завжди містить проективні компоненти, без яких історія дитинства неможлива. 3 огляду на хронологічні межі класифрікації, створеної американським психоаналітиком, ми розуміємо, що час написання Р. Ешемом трактату співпадає з так званим амбівалентним періодом. Ця амбівалентність простежується на рівні висвітлення таких ключових питань у процесі виховання:

- як зробити процес навчання більш простим і приємним (cherefullie and plainlie) для самого учня, а не більш легким для вчителя [9];

- хороше навчання - це процес, у якому "<...> the master shall teach without all error, and the scholer shall learne without great paine: the master being led by so sure a guide, and the scholer being brought into so plaine and easie a waie" [9];

- хороший учитель-це не той, хтодобре б'є: "Who many times, punishe rather, the weakenes of nature, than the fault of the Scholer" [9];

- хороший учень може зненавидіти навчання через різки значно швидше, ніж навчитися чогось: "Whereby, many Scholers, that might else proue well, be driuen to hate learning, before they knowe, what learning meaneth: and so, are made willing to forsake their booke, and be glad to be put to any other kinde of liuing" [9];

- те, що вивчається поза доброю волею самого учня, тобто без внутрішньої мотивації, так само швидко забувається: "For what soeuer the mynde doth learne vnwillinglie with feare, the same it doth quicklie forget without care" [9];

- у процесі навчання відповідальними $€$ три сторони: батьки, учень і вчитель: “< ..> nо Scholemaster hath charge of any childe, before he enter into hys Schole, therefore I leauing all former care, of their good bringing vp, to wise and good Parentes, as à matter not belonging to the Scholemaster" [9];
- безпосередньо тільки знання не є метою; знання $€$ необхідним підґрунтям для напрацювання відповідних навичок: "But, to go forward, as you perceiue, your scholer to goe better and better on awaie, first, with vnderstanding his lesson more quicklie, with parsing more readelie, with translatin more spedelie and perfitlie then he was wonte, after, giue him longer lessons to translate: and withall, begin to teach him" [9].

Принципи ефрективного навчання, яке в наш час ми називаємо інтерактивним, були озвучені ще в XVI ст., зокрема: "Let your Scholer be neuer afraide, to aske you any dout, but vse discretlie the best allurements ye can, to encorage him to the same: lest, his ouermoch fearinge of you, driue him to seeke some misorderlie shifte: as, to seeke to be helped by some other booke, or to be prompted by some other Scholer, and so goe aboute to begile you moch, and him selfe more" [9].

Отже, ми бачимо свідчення того, що Р. Ешем окреслив позиції, у яких тісно перепліталися елементи християнсько-схоластичного підходу (адже твердження автора в передмові до твору про те, що "In writing this booke, I haue had earnest respecte to three speciall pointes, trothe of Religion, honestie in liuing, right order in learning" [9], $\epsilon$ відлунням більш давньої традиції) та гуманістичної педагогіки, центром якої $є$ насамперед інтереси учня (дитини), яка $є$ беззахисною з огляду на відсутність життєвого досвіду. Саме онтологічний досвід, яким може свідомо оперувати особа, а не вікові межі є однією з особливостей рецепції дитини відповідно до тексту трактату. Читачам заявлені тези не здаються безапеляційними й суто схоластичними завдяки активному застосуванню письменником-гуманістом дескриптивних мініісторій. Ці життєві приклади, на думку Д. Сейнтсбері, є автобіографрічними як за змістовими компонентами, так і за формальним, мовним оформленням, оскільки в них зафріксований своєрідний потік думок, характерний для самого автора [11, с. 30].

Концептуально новою позицією, саме гуманістичною, було розуміння автором того, що рушійною силою у процесі виховання особистості, крім вітального досвіду, можуть бути також індивідуальні особливості кожної окремої людини та обставини, у яких вона перебуває. Ці обставини впливають і на результат навчання, наприклад: "We passed from // this booke children and came to yonge men, namely, lentlemen $<\ldots>$ of witte gathered, and good fortune gotten, by some, onely by experience, without learn- 
ing" [9]. Тобто результатом взаємодії вчителя та учня може бути здобуття розуму, отримання досвіду та покращення статків. Завдяки цій тезі автора читачі отримують експлікацію як результатів навчання, так і компонентів, що $є$ необхідними для відокремлення рецепції дорослої людини від рецепції дитини. Те, що ці компоненти $€$ взаємодоповнюючими й необхідними, Р. Ешем підсилює прикладом про те, що книга може замінити 20 років власного досвіду та зробити процес набуття життєвої мудрості й щастя, тобто дорослішання, менш болючим [9].

Спостерігаючи за процесом навчання, Р. Ешем чітко визначає, що всіх учнів можна диференціювати за швидкістю сприйняття та за якістю застосування сформованих навичок. Він виокремлює дві категорії учнів - носіїв так званих "quick wit" i "hard wit". При цьому, що цікаво, він не надає суб'єктивну оцінку та не визначає, що є кращим чи гіршим, а об'єктивно аналізує причинно-наслідкові зв'язки, характерні для представників обох категорій. Також Р. Ешем озвучує своєрідні «методичні» поради наставникам із приводу методів навчання: "For, if one, by quicknes of witte, take his lesson readelie, an other, by hardnes of witte, taketh it not so speedelie: the first is alwaies commended, the other is commonlie punished: whan a wise scholemaster, should rather discretelie consider the right disposition of both their natures, and not so moch wey what either of them is able to do now", проте не засуджуючи, а радше створюючи "ситуацію успіху", якщо послуговуватися сучасним педагогічним термінологічним словником. Не проходять повз увагу ренесансного гуманіста також способи навчання, ефективні для суб'єктів із різними особливостями сприйняття, тому сучасна теорія Г. Гарднера про множинність інтелектів і способи навчання здається вже не зовсім новою [10].

Якщо говорити про передумови такого розподілу типів інтелектуальної діяльності, то ними $€$ виокремлення періоду несвідомого, "pure cleane witte", який автор порівнює 3 воском, що не зазнав впливу жодних фракторів: "For, the pure cleane witte of a sweete yong babe, is like the newest wax, most hable to receiue the best and fayrest printing: and like a new bright siluer dishe neuer occupied, to receiue and kepe cleane, anie good thyng that is put into it" [8]. Тобто можемо спостерігати першу істотну трансформацію рецепції дитини, зокрема: дитина є вже не просто ємністю для однаково ретрансльованих знань, а певним своєрідним матеріалом, який потребує певних зусиль із боку як наставника, так і самого учня. Таким чином, егоїстичне бажання «наповнити» учня трансформується у процес активного напрацювання "good wit", компонентами якого $€$ і книги, і власний досвід, і доля. Така позиція гуманіста прийшлася до смаку багатьом його сучасникам, тому не дивно, що зазначені дефініції трапляються в подальших роботах митців періоду Ренесансу.

Варто звернути увагу на той факт, що своєрідним рефреном, яким Р. Ешем супроводжує свої тези, є твердження про те, що навчання має бути простим, легким, грайливим. Це свідчить про те, що завдяки власній спостережливості автор добре знайомий із фактом, що домінуючим видом діяльності в період становлення людської особистості, який ми звикли називати дитинством, $є$ саме ігрова діяльність, у процесі якої особистість формує власне уявлення про навколишній світ. На зміну їй приходить комунікативний вид діяльності, у процесі якого особа отримує аксіологічний досвід. Третім видом домінуючої діяльності $€$ трудова, проте з нею на текстовому рівні паралелі відновлюються досить важко: про трудову діяльність, яка в сучасному суспільстві сприймається вже як певний елемент зрілості, у трактаті не йдеться.

Висновки і пропозиції. Таким чином, хоча ми можемо тільки приблизно реконструювати вікові межі дитинства завдяки сторінкам трактату, проте розуміємо, що це процес розвитку від "pure cleane witte" до початку свідомого користування своїм уже сформованим "good witte". На зміну середньовічному однобічному трактуванню поняття «дитинство» приходить розуміння важливості взаємодії тріади «учень - батьки - школа». Відлуння тверджень Р. Ешема ми зустрічаємо не лише у творах єлизаветинської епохи, а й у сучасних психологічних, методологічних і дидактичних розвідках, гіпотези яких підтверджені науковими фактами та результатами експериментів. На відміну від сучасних науковців, які суттєво озброєні технологіями сьогодення, Роджер Ешем як основне джерело знань використовував роботи античних митців і власну спостережливість, а також реалізовував на практиці саме гуманістичну концепцію виховання, у центрі якої перебуває Людина. 


\section{Список використаної літератури:}

1. Аверинцев С. Древнегреческая поэтика и мировая литература. Москва : Наука, 1981. 368 с.

2. Арьес Ф. Ребёнок и семейная жизнь при Старом порядке. Екатеринбург : Изд-во Уральского университета, 1999. 416 с.

3. Баткин Л. Итальянское Возрождение: проблемы и люди. Москва : Изд-во Российского государственного гуманитарного университета, 1995. 448 c.

4. Василина К. Англійський конні-кетчерівський памфрлет в контексті шахрайської прози XVI ст. URL: http://old.lingua.Inu.edu.ua/ Foreign_Philology/Foreign_Philology/Foreign_ Philology_119_1/index.html.

5. Де Моз Л. Психоистория. Ростов-на-Дону : Феникс, 2000. 454 с.

6. Кон И. Бить или не бить? Москва : Время, 2012. $448 \mathrm{c}$.
7. Пиаже Ж. Генетический аспект языка и мышления. Психолингвистика : сб. статей. Москва, 1984. C. 130-145.

8. Торкут Н. Проблематика та жанрова своєрідність етико-педагогічного трактату Р. Ешема «Шкільний вчитель». Вісник Запорізького державного університету. Серія «Філологічні науки» / гол. ред. В. Толок. Запоріжжя:Запорізькийдержавнийуніверситет, 1999. C. $137-143$.

9. Ascham R. The Schoolmaster. URL: http:// www.gutenberg.org/cache/epub/1844/pg1844-i mages.html.

10. Hardner H. Frames of Mind. URL: https://manyebooks.org/download/frames_of_mind_the_theory_multiple_intelligences_howard_gardner.pdf.

11. Saintsbury $\bar{G}$. A history of Elizabethan Literature. New York : Russell \& Russell, 1970. $230 \mathrm{p}$.

\section{Hutaruk N. Iconic and discursive character of representation of child in "The Schoolmaster" by Roger Ascham}

The researcher's attention is focused on the treatise "The Schoolmaster" (1570) written by the Tudor writer Roger Ascham. The treatise consists of two books. While the first one is devoted to describing effective teaching methods and the features of the ideal tutor; the second part is an attempt to endorse using of bilingual translation in process of learning foreign languages.

The article is aimed to analyze the first part of the treatise which is rich in practical advice given by the early humanist to teachers, parents and students. Therefore it enables the scholars to reconstruct the peculiarities of Renaissance perception of child.

Though we easily can elicit in "The Schoolmaster" the ideas of eloquent Greek authors about education, they are supported with vivid descriptive scenes from life of Elizabethan society. These evident situations expand the possibilities of researches to define the details of author's binary opposition: "quick wit" and "hard wit", presented for the first time. This opposition is illustrated through descriptive author's analysis of education process and its consequences. Moreover, it is highlighted that in successful process of education parents, children and teacher have equal responsibilities. Depicting the routine practices $R$. Ascham sheds the light upon such controversial issues as:

- how to make the process of education more enjoyable and simple;

- what can be considered a good education/teacher/pupil;

- how to enforce pupils' intrinsic motivation;

- how to bring principles of efficient learning closer to natural human development, etc.

To conclude, many of the answers given by R. Ascham in "The Schoolmaster" led to successful attempts of reconstruction the main constituents of perception of child peculiar for Renaissance period.

Key words: child, childhood, Renaissance, ethics and pedagogical treatise, Christian-scholastic approach. 